\section{Private Estates and Forestry}

A PAPER on this subject was read by Major C. P. Ackers before the Royal Society of Arts on February 26,1941 . Some introductory remarks on the history of forestry in Great Britain were made and forestry education was alluded to. It is incorrect to say that forestry education seriously started at Oxford under the late Sir William Somerville. The late Sir William Schlich took forestry to Oxford when the R.I.E. College, Coopers Hill, was closed in 1905. Somerville was the first lecturer in forestry at the University of Edinburgh; afterwards his connexion was with agriculture. Major Ackers correctly states that the position of British woodlands of all types and ownership had sunk to a very low management before the War of 1914-18 and with the exception of the afforestation work of the Forestry Commission and a few isolated private instances the management has scarcely improved since.

Some of the author's ideas for improvement of forestry in Great Britain will not receive general endorsement. Sylviculturally the suggestion that whenever the prospects are reasonably in favour, mixed crops of conifers and hardwoods should be grown, is sound. Such mixtures are admittedly more difficult to manage than pure crops or mixed crops of conifers. But it is true to say that in many parts of England and certain parts of Scotland and Wales they would fulfil soil requirements and the local country-side markets, besides re-introducing small local industries. Although it must remain true that Great Britain could never grow enough wood, etc., to supply the requirements of its population, yet with equal truth it may be asseverated that a long-term policy is essential. Such an indispensable condition has so far never been conceded by either Government or private owner.

\section{Swine Influenza in Britain}

IN a paper on this subject read before the Section of Comparative Medicine of the Royal Society of Medicine on April 23, Mr. F. Blakemore said that swine influenza has been extensively studied in America and a somewhat similar disease named Ferkelgrippe has been described in Germany and most European countries, including Northern Ireland. It has not been recorded in Great Britain, but many clinicians maintain that a specific pneumonia causes considerable loss, so that it is important to study the etiology of the disease and ascertain its relationship to conditions investigated elsewhere. An outbreak of influenza affecting pigs 10-14 weeks old in which the symptoms were typical of those described by Shope in America was investigated. In severe cases there was a lobular pneumonia affecting principally the anterior lobes. The mortality was low but recovery was slow.

Hamophilus influenzoe was recorded from half the pigs examined, and the presence of a virus was demonstrated by the intranasal instillation of a filtrate of pneumonic lung. The virus was afterwards established in ferrets, and neutralizing antibodies were demonstrated in the blood of convalescent pigs to the ferret-adapted virus. An investigation of a further four selected outbreaks of pneumonia in pigs revealed the presence of a virus and in two of these the agent was adapted to the ferret. Homophilus influenzce was obtained from only a few of the pigs; other infecting bacteria were Pasteurella suiseptica, $B r$. bronchiseptica, Salmonella, streptococci and unidentified Gram-positive bacilli. An attempt was made to ascertain the incidence of influenzal pneumonia by examining the lungs of pigs at a public slaughterhouse. Lesions of the kind found in outbreaks previously studied were observed in a proportion of cases. Hamophilus influenzoe was recovered from three of forty affected lungs obtained from the slaughterhouse. Transmission experiments with material from two lungs were carried out. The disease was readily reproduced in pigs, and one of the strains was later adapted to the ferret.

\section{Effect of Low Temperatures on Aircraft Metals}

Temperatures as low as $-60^{\circ} \mathrm{C}$. may be reached by parts of the structures of aircraft flying at great heights. S. J. Rosenberg (J. Res., Nat. Bur. Stand., 25,673 ; 1940) has examined the effect of low temperatures, down to $-78^{\circ} \mathrm{C}$., upon the tensile properties, hardness, and impact resistance of metals commonly used in building aircraft. For the materials tested, including ferritic steels, austenitic stainless steels and nickel alloys and light metal alloys (Aland Mg-base), none of these mechanical properties was adversely affected by low temperatures with the exception of a decrease in impact resistance of ferritic steels as the temperature fell. In common with all papers published in this journal, the present paper may be bought as a separate reprint (Research Paper R.P. 1347), from the Superintendent of Documents, U.S. Government Printing Office, Washington, D.C.

\section{Dr. James Hope}

Dr. James Hope, one of the most eminent London physicians of the first half of the nineteenth century and one who contributed much to our knowledge of diseases of the heart, was born at Stockport, Cheshire, on February 23, 1801, the tenth of a family of twelve. He studied medicine at Edinburgh, where he qualified in 1825 with a thesis on aneurysm of the aorta. After spending two years in foreign travel including a year in Paris under Chomel, he settled in London. in 1828 and soon acquired an extensive practice. $\mathrm{He}$ made numerous contributions to periodic literature on heart disease, and in 1831 published his chief work entitled "A Treatise on Diseases of the Heart and Great Vessels", which comprised a new view of the physiology of the heart's action according to which the physical signs are explained. In the following year he was elected a fellow of the Royal Society. In 1834 he was elected assistant physician and in 1839 full physician to St. George's Hospital. His second most important work was published in 1833 and 1834, entitled "Principles and Illustrations of Morbid Anatomy adapted to the Elements of 
M. Andral and to the Cyclopædia of Practioal Medicine, being a complete series of coloured lithographic drawings from originals by the author". $\mathrm{He}$ died on May 12, 1841, at the early age of forty.

\section{Spectrochemical Literature}

THE second volume of Spectrochemical Abstracts, covering the years 1938-39 and edited by E. H. S. van Someren, has just been issued by Messrs. A. Hilger, 98 St. Pancras Way, N.W.1. More than 150 papers and books are listed under authors' names, and the classification of substances analysed and elements determined is very thorough. The pamphlet is a valuable summary of material scattered in many journals.

Books and papers of metallurgical interest are similarly covered by the Bibliography of Spectrochemical Analysis compiled by D. M. Smith and published by the British Non-Ferrous Metals Research Association, Euston Street, N.W.1. The second edition, costing three shillings, has been brought up to date, to August 1940, and now includes more than five hundred entries. A new section on Application of the Microphotometer lists twenty-one researches. Short explanatory notes are given with most of the references and an author index is provided.

\section{Earthquake in Manchuria}

AN earthquake of considerable intensity is reported to have taken place early on May 6 in northern Manchuria. Insufficient reports have so far been received to fix the epicentre with any precision but it must have been fairly close to Suihwa, forty miles north-east of Harbin, where thirty-three were killed and several injured. It is also reported that scores were killed and injured in other nearby cities. It will be recalled that one of the larger earthquakes of 1940 took place in Manchuria on July 10.

\section{Institution of Electrical Engineers: Awards}

THE Council of the Institution of Electrical Engineers has made the following award of premiums for papers read during the session 1940-41, or accepted for publication : Institution Premium : Mr. C. F. Booth; Ayrton Premium : Mr. W. A. Cook; Fahie Premium: Messrs. A. Fairweather and J. Ingham; John Hopkinson Premium: Mr. G. H. Rawcliffe; Kelvin Premium : Messrs. C. E. R. Bruce and R. H. Golde; Extra Premiums : Mr. C. G. Garton, Messrs. L. Gosland and W. F. M. Dunne, Prof. Willis Jackson and Mr. A. E. Chester, Dr. R. Jessel, Messrs. W. J. Mason and S. A. G. Emms, Mr. G. H. Metson, Mr. A. Langley Morris; Wireless Section Premiums : Messrs. N. M. Rust, O. E. Keall, J. F. Ramsay and Dr. K. R. Sturley (Ambrose Fleming Premium), Messrs. C. A. Mason and J. Moir, Dr. R. H. Barfield; Meter and Instrument Section Premiums : Dr. A. E. W. Austen and Dr. S. Whitehead, Mr. A. J. King, Dr. R. W. Guelke, Mr. C. R. Maguire and Dr. R. A. Scott; Transmission Section Premiums : Mr. F. R. Perry (Sebastian de Ferranti Premium), Dr. C. Dannatt and R. A. Polson.

\section{Announcements}

The Sir John Kennedy Medal of the Engineering Institute of Canada has been presented to LieutenantGeneral A. G. L. McNaughton, commander of the Canadian Corps in Great Britain and lately president of the National Research Council of Canada. General McNaughton described the present position of research in Canada before a meeting of the Royal Society of Arts on May 13; we hope to print a substantial part of this lecture in an early issue.

Prof. L. G. M. BAAs BECKING, professor of botany in the University of Leyden and director of the well. known Leyden Botanical Gardens (NaturR, 142, 1013 ; 1938), is now in custody in a prison at Scheveningen, Holland.

Dr. Thomas Midgley, Jun., of Kinetic Chemicals, Inc., has been awarded the Priestley Medal, the highest award of the American Chemical Society, for his discovery of the anti-knock properties of tetraethyl lead, as well as other outstanding achievements in chemical science. Dr. Midgley has already been awarded the Nichols, Longstreth and Perkin Medals.

The thirty-first annual May Lecture of the Institute of Metals will be delivered in the New. Clarendon Laboratory, Oxford, by Dr. F. Simon, reader in thermodynamics in the University of Oxford, on May 28. Dr. Simon will speak on "The Significance of Low Temperature Research". Admission is by ticket, obtainable free of charge, from the Secretary, Institute of Metals, 4 Grosvenor Gardens, London, S.W.1, or the Secretary, Clarendon Laboratory, University Museum, Oxford.

THE following appointments in the Colonial Service have recently been announced: D. T. Lloyd, surveyor, Sierra Leone; E. B. Lambert (assistant superintendent of Crown lands), superintendent of Crown lands and surveys, Hong Kong; L. Lord (formerly divisional agricultural officer, Ceylon), secretary to Colonial Advisory Council of Agriculture and Animal Health and assistant to Agricultural Adviser, Colonial Office.

THE following appointments in the University of Sheffield have recently been made : Dr. S. A. Peyton, University librarian; Mr. F. J. S. Esher, assistant lecturer in mental diseases; Mr. M. Laird, junior demonstrator in anatomy ; Mrs. Mildred John, parttime demonstrator in anatomy.

The Council has received from the executor of the late Mrs. E. G. Willis a cheque for $£ 1,000$ in payment of a legacy left to the University for the foundation of a scholarship in engineering or metallurgy in memory of her late husband, Mr. T. W. Willis.

The collaborators of the late Prof. R. V. Wheeler have presented to the University a complete set of his published researches, together with a glass cabinet to contain the volumes.

The Council has received the resignation of Dr. F. E. E. Schneider of his post of assistant lecturer in mental diseases, and Mr. T. C. Joyce of his post of lecturer in electrical engineering. 